\title{
Cysteine-rich domain of scavenger receptor Al modulates the efficacy of surface targeting and mediates internalization of oligomeric beta amyloid
}

\author{
Huey-Jen Tsay \\ From Molecular Neurodegeneration: Basic biology and disease pathways \\ Cannes, France. 10-12 September 2013
}

\section{Background}

Scavenger receptor class A (SR-A) of microglia and macrophage mediates the internalization of oligomeric amyloid- $\beta$ peptide (oA $\beta$ ) and low-density lipoprotein in Alzheimer's disease and atherosclerosis. SR-A is a member of the cysteine-rich domain (SRCR) superfamily, but the function of the SRCR domain is unclear.

\section{Materials and methods}

We investigated whether the SR-AI SRCR domain encoded by exons 10 and 11 modulates receptor surface targeting, ligand internalization, and extracellular matrix adhesion by expressing mutated SR-A variants in COS-7 cells.

\section{Results}

We found that SR-A variants with truncated exon 11 were intracellularly retained, whereas SR-A variants with further truncation into exon 10 were surface-targeted. Surface-targeted variants were fully glycosylated, whereas intracellularly-retained variants remained in high-mannose states. The fusion of exon 11 with a surface-targeted SR-A variant resulted in intracellular retention and a high-mannose state. Both the SRCR and collagenous domains mediated the ligand binding, but the collagenous domain was more important for matrix adhesion. Point mutations in a long stretch of $\beta$ sheet 1 , 2 and a loop region between $\beta$ sheet 4 and 5 of the SRCR domain resulted in intracellular retention and a high-mannose state.

Institute of Neuroscience, National Yang-Ming University, Taipei, Taiwan

\section{Conclusions}

By identifying the function and critical motifs of the SRCR domain, our study suggests possible approaches to modulate innate immunity in Alzheimer's disease and atherosclerosis.

Published: 13 September 2013

doi:10.1186/1750-1326-8-S1-P43

Cite this article as: Tsay: Cysteine-rich domain of scavenger receptor Al modulates the efficacy of surface targeting and mediates internalization of oligomeric beta amyloid. Molecular Neurodegeneration 2013 8(Suppl 1):P43.
Submit your next manuscript to BioMed Central and take full advantage of:

- Convenient online submission

- Thorough peer review

- No space constraints or color figure charges

- Immediate publication on acceptance

- Inclusion in PubMed, CAS, Scopus and Google Scholar

- Research which is freely available for redistribution

Submit your manuscript at www.biomedcentral.com/submit
C Biomed Central

\section{Biomed Central}

(c) 2013 Tsay; licensee BioMed Central Ltd. This is an Open Access article distributed under the terms of the Creative Commons Attribution License (http://creativecommons.org/licenses/by/2.0), which permits unrestricted use, distribution, and reproduction in any medium, provided the original work is properly cited. 